\title{
Assessment of As-siddeek Savings Cooperative Limited's Goodwill Valuation
}

\author{
Chinasak Suwan-achariya (Corresponding author) \\ Faculty of Economics and Business Administration, Thaksin University \\ 140 Karnchanavanich Road, Muang Songkhla, 90000, Thailand \\ Tel: 668-6857-7501Ｅ-mail: Chinasak2000@yahoo.com
}

Kalasom Lahteh

Faculty of Economics and Business Administration, Thaksin University

39 M. 11 Thachang Municipality, Bang Klam District, Songkhla Province, 90110, Thailand

Tel: 668-6964-9579 E-mail: kalasom2010@hotmail.com

Received: January 16, $2011 \quad$ Accepted: July 5, $2011 \quad$ doi:10.5539/ijef.v3n4p151

The research is sponsored by As-siddeek Savings Cooperative Limited's

\begin{abstract}
In the current economic crisis occurs the intensity of severe competition for customers finding.

Therefore, agencies and organizations are focused on the role of assets which are non-material, particularly goodwill, it is able to create a good image to customers and have an established base, importantly, it also is able to add value to the organization. As-siddeek Savings Cooperative Ltd. is currently an organization where focused on it, so that the applicable marketing with religion to the credit transaction has happened.

As a result, the study found that the exchange of agreement in accordance with a legal act to partnerships between the cooperative's memberships to comply with the principles of Islam what cause the low transaction cost, forming the principles of marketing in the type of the saving and trade cooperative effects in growth including customer base. Confidence to the financial stability to the cooperative and the occurring goodwill to members and breadth its customer base is the source of abundant profit for practical that reflected in financial reports that are different from the general cooperatives.
\end{abstract}

Keywords: Goodwill, Transaction cost, Applied market system of religious approach, Abundant profit, Customer base (membership)

\section{Introduction}

Competition often is inherently in every organization. From the actual situation, today's competition is intangible assets, which is a long-term competitiveness that requires a unique identity in accordance with the nature of each organization according to different traditions. This reflects intangible assets of an organization that is good reputation of business or Goodwill for each organization.

As-siddeek savings cooperative Ltd. is Islamic financial institution leading practices into the organization to drive business to the formation in a new dimension that a meaningful in connection with the assessment of goodwill valuation toward the principles of Islam what reflect to the success that is the source of increasing membership base in the organization, continuously.

Article in this research studies the principles of action which are form the principles of religion to drive the economic activities of the organization with a mission to answer questions about the organization in market system when the religious approaches are applied with marketing. How is the size of transaction cost in a cycle of loan? Moreover, the assessment of goodwill valuation and the structure of the cooperative's goodwill also.

\section{Methodology}

Research methods in sociology were used the assessment with reference to the size of transaction cost and the structure of cooperative's goodwill, which is the source of membership base of the cooperative and numbered 
analysis of the cooperative's accounts as the principles of account which are mainly non-material assets that are not objects in business profit.

In the research has been accepted the two types as the primary data and secondary data.

Primary data includes data from the record of transaction cost in working performance that reflects the efficiency of the principles of Islam which are used. All above expressed that the size of transaction cost what occurs from working as practice process in a cooperative. During the retention is a week to assess the size of transaction cost in the size of time's expenditure in working performance apart from the rules and regulations of the cooperative. In additional, the data from the interviews which provide the result as 2 ways, the first is evaluating the arising size of transaction cost from a cycle of the agreement in accordance with a legal act and the other side shows the structure to increase savings and investment in the cooperative from the influence of cooperative's goodwill that effects from the investment. As a consequence, it has been made the membership with the overview of cooperative about the great famous effect to membership the increasing savings in the cooperative as well. The data were collected from September to December 2010 in which the mentioned data from two sources as the study of empirical data. In the interview process, the researcher has used the process is a random population who got the agreement in accordance with a legal act and co-activities with the cooperative at least 1 year. The case study of population in Thachang Municipality, Bang Klam District, Songkhla Province was conducted by sampling with Semi-Method of Taro Yamane. The numbers of representative samples are 40 samples.

Secondary data is information from the numbers of fiscal years 2007, 2008 and 2009 to state the compensation on revenue and the transaction cost of cooperative affecting information relating to the cooperative's goodwill by the figure of account that reflects the goodwill valuation what causes the increase of the cooperative's membership base.

\section{Literature review}

Concept of the principles of Islam is used the financial system. Especially, the agreement is meant highly in practice, for instance, the principles of trade replaces the money lending's system in the form of interest what is not allowed under the principles of Islam. Evidence in al-Quran that "Allah the lord approved to do trade, the lord has not allowed the other principles with interest"(Al-Quran, Surah Al - Baqarah Ayah 275). The principles of loan are without surplus amount of the loan. The partnership in activities performance that do not allow the equivocation from the principles of God that applies strictly voluntary, it associates with the size of transaction cost in the economic activities performance with reference to exchange the agreement for the two parties. The transaction cost is costs that are associated with the using of market mechanisms can be divided into the cost in collecting and interpreting data, the cost of negotiation and decision and the cost of control for protection to practice under the agreement.

Coase has determined the transaction cost effect to the expenditure on each part of the economic activity that the activities and expenditure arise from the process of agreement, it means the cost effect to the coordination and collaboration of the economic host in the type of market economy. Coase called that the transaction cost of collaboration between buyers - sellers and the occurring market (Coase R.H:1992, 29). Jones and Hughes have determined the transaction cost as the cost in terms of agreement tracking and the agreement tracking which occurs the agreement access (Jones G.R., Hill C.W:1982,160) Nicolson thought that the transaction cost arises from the clear and unclear expenditure when the clear expenditure is the type of expenses and services of middlemen. While the unclear expenditure is the expense of data search and information using. M Aleksejev agreed that the transaction cost is trade agreements that cause the expense in transaction, representing the arising expense from the search for a buyer or seller, behavior of negotiations about the topic in the agreement including service fee payment for advice and other services (Aleksejev M:1997,127). Chueng (Chueng S: 1978, 158) agreed that the exchange participation is more than two or up causing the transaction cost relatives more expenditure. In additional, the cost of production Menar (Menar K: 1996, 29) understood that the transaction cost is the expense in function of the exchange system or accuracy in the type of market economy that is the usable value in market for the allocation of resources and transfer ownership, Menar thought the transaction cost as emergency expenditure because it caused by exchange.

Therefore, research has identified the transaction cost of Savings Cooperative as the cost of infrastructure in operations to the membership due to the communication recognized the information thoroughly and the cost of behavior tracking its members to perform according to the agreement which results the value of cooperative because the value of cooperative includes various assets.

One of the assets of cooperative effects the abundant profit is goodwill as assets which are non-material regarding a good reputation which the qualitative composition of organization. The paper (American society of appraiser: ASA) has defined goodwill as well-known activities of the company and customer relationships in the set position. The products list that is produced as factors that each part is not separated and is not assigned for the report of 
establishment but the service accesses a source of real income. (Bolshoj juridicheskij slovar) Pissley indicated that a goodwill of all companies are able to earn the higher profits than general profits which the abundant profit is understood as the increasing size than general income indicators. (Scherbakova O:2008,1) Calculation the rate of profits in investment of establishment each branch with considering the nature of risks about such business.

The researcher agrees with the theoretical concept of MM (Miller-Modilyanee) that indicated the influence of various assets in the company's valuation which is determined by the money flowing, it is not based on the asset structure of the establishment. .( Valuation of Personal Goodwill:2003,17)

The same standing point has accorded the papers as Gryaznova G, Fedotova M that goodwill is assets which are non-material of the establishment was defined as a good reputation, business relationships, the name of the company is known and brand. Goodwill was made under the increasing rate of profits securely to establishment rather than general profits in the manufacturing sector or services sector (Gryaznova G., Fedotova M:1999, 496).

Relating to this research, the researcher has analyzed if provides the weight to management team and formation the suitable that fits with the principles of religion, defined by God who is driven to operate; it can understand the meaning and influence of the goodwill.

Therefore, the ownership in the model of group as cooperative claims services to its members greater flexibility for right's owner in ownership. At the same time the right's owner has to share responsibility to make sustainable using of the asset although guidelines for cooperative services management what takes the principles of religion use, in the other hand, due to the reciprocal of assets within the cooperative together. As users and owners, it can cause the transaction cost that can not avoid by the assessment method and definition the size of transaction cost of the cooperative have not tools and studying this pragmatic work.

The researcher, thus, has a concept of the assessment of goodwill valuation from definition of the occurring size of transaction cost that is overlapping with the principles of religion by measurement the transaction cost of the cooperative from a cycle of week with lending. Expression opportunity cost in working performance of the management team is a group of services to memberships, which means the beginning of agreement between two parties as cooperative team and membership. From an effective environment that is used on the size of transaction cost of the team and measurement the transaction cost of membership acquiring in the exchange of agreement in accordance with a legal act toward management team. Such practice guidelines are culture under environment of the principles of Islam in the formation which acquire the agreement that is reflected in the meaning of goodwill. Moreover, the assessment of goodwill valuation is also a problem in valuation that is not clearly complaint to resolve the issue. (See figure 1 Framework for research).

This research article, the researcher evaluates the goodwill valuation on the basis of compensation on revenue, the transaction cost and the growth of long-term investment against assets are not-material for the goodwill valuation that reflected in the figure of account in the year since 2007 to 2009.

\section{Results and discussion}

\subsection{The assessment of the size of transaction cost from the formation of goodwill.}

Due to the study, the financial transaction cost of the cooperative by assessment the size of transaction cost in terms of losing time apart from normal working performance in a cycle of week with lending (see Table 1).

Perceptible information is not clear in the agreement of membership in a week found that expresses the transaction cost of employees based wage rate, representing the size of 123.90 Baht (see Table 2). $66.67 \%$ of the persons who ask for new information as the first position and solution of membership with reference to credit access as the second ranking. $25 \%$ of the misunderstanding of process to credit access including $8.33 \%$ of the last position has other methods apart from the principles of practice to credit access.

Credit consideration of credit access to membership with connection the missing documents effected to reproduce in term of time as 31.50 Baht.

The cost of agreement in negotiations between a borrower, a guarantor and employees, representing 21.00 Baht. It demonstrates the lack of effective coordination between them.

Trade and services found that the cost of connection after the agreement has been negotiated, representing 141.00 Baht to the cost to reduce the following risk from the subsequent opportunistic behavior of its members but has not been prepared.

The accelerate debt showed that 2 in 3 persons of the successful negotiations show up the successful compromise according to the principles of religion in terms of the cost of negotiations indicated that the occurring transaction cost by $2 / 3$ of the contagious membership as 31.50 Baht. 
The debt tracking is the cost regarding finding and negotiating. Fieldtrip per a day arises opportunely the transaction cost amount 5 persons which are finding and negotiating at least 2 times as it was not found and the occurring obstacles in public as 882.00 Baht.

Investment activities are the cost of coordination between all participants, ranging as 74.25 Baht.

The invention of brand standards is the cost of coordination both the inner image and outer image. Integration results the quality improvement of its arising brand as size 1363.36 Baht in a cycle of month, so the using of figure " $1 / 4$ " reflect the size of transaction cost in the inventive standard brand in a cycle of week, which was the size as 340.84 Baht.

The principles of corporation's marketing are the claim to the existence of membership in organization which is the occurring cost of negotiations by showing the flexibility of practice in membership being by negotiations the using of emergency funds, it means the amount of such shares to the remaining membership.

Relating to analysis the transaction cost in term of the losing time in practice stated that the transaction cost in a week as 1,690.99 Baht representing $12.60 \%$ of time's price in working performance as 13,421.13 Baht.

Therefore, the structure of cost regarding working performance in a week can be expressed by equation

$\mathrm{C}_{\mathrm{s}}=\mathrm{C}_{\mathrm{sc}}+\mathrm{C}_{\mathrm{f}}$

By that $C_{s}$ is the structure of cost

Csc is the cost with reference to the structure of changes.

$\mathrm{Cf}$ is the cost with reference to the duty of changes.

When $\mathrm{Cf}$ is responsible for the costs associated with the duty of the acquiring agreement. (Requests for information that is not clear, consideration, the agreement and trading) and Csc is the cost which is not related about agreement. (The accelerated debt, the debt tracking, investment activities, the invention of brand standards and the principles of marketing), the cost of structure is all about $1,690.99$ Baht or $12.60 \%$ of the time in working performance as 13,421.13 Baht.

\subsection{The Assessment of Goodwill Valuation for As-siddeek savings cooperative Ltd.}

The occurring assessment of cooperative's goodwill includes the structure of transaction cost in a cycle of member's lending relating to the financial transactions from the principles of religion causing an overview of the goodwill in the market that reflected in the figure of account of the existence of goodwill as assets to the organization.

The structure of transaction cost in a cycle of lending included credit information research, the cost of negotiations to select the type of agreement and the cost of the quality research of its brand of membership and representing a cycle of the agreement price that this is a commercial agreement with the study from the persons who were interviewed.

From comparison of the proportion of credit access by ordinary and special agreement $97.22 \%$ of traders or wages to credit by passing a product called "the credit giving by money is touching". While the emergency agreement was all $100 \%$ of the persons who use money to pay debts accessed by sending the money through as the credit giving by money is touching (see Table 3).

For $2.77 \%$ of the products and services access delivered through an emergency agreement and the results showed that the credit access is associated with a network together. Representing, the information access is rather than $97.5 \%$ as the persons who were interviewed by the cost of information finding can have the following table.

Comparison the size of the expenditure shows that finding from a network of relatives and friends may not occur the cost if they are identified by a nearby home. It was arising 50\% from finding by relatives and friends. The second position, finding from a network of friends in the cooperative consists of the most cost is in connection, representing $40 \%$ of the person who search from a friend in the cooperative. Cooperative finding is directly which will be the occurring opportunity cost as $52.63 \%$ of the person who search from the cooperative. In additional, finding both the two ways have the occurring opportunity cost $66.67 \%$ of finding both the two ways. However, the finding cost will not occur if there is a complete understanding of the data in the process of membership training of the cooperative (see Table 4).

The cost analysis with reference to finding the information represents by the equation formula.

$\mathrm{CD}=\Sigma_{\mathrm{i}}{ }_{\mathrm{i}}={ }_{1}(\mathrm{Cn}+\mathrm{Cf}+\mathrm{Co})$

By that 
$\mathrm{CD}$ is the cost of information finding.

$\mathrm{Cn}$ is the connection (by phone).

$\mathrm{Cf}$ is the cost of fuel.

Co is the opportunity cost.

The analysis stated that the total cost to the information finding amount 40 persons as 2,166 Baht or $0.07 \%$ of the total lending amount 2,973,000 Baht.

The size of the cost of negotiations included the cost in the process of filing and the process of agreement which consist of documentary expenditure to connection bondsman, the cost of fuel, the opportunity cost and expenditures associated with the price assessment of assets cause the cost by the equation.

$\mathrm{Ce}=\Sigma_{\mathrm{i}}^{40}={ }_{1} .(\mathrm{Cd}+\mathrm{Cc}+\mathrm{Cf}+\mathrm{Co}+\mathrm{Ca})$

By that

$\mathrm{Ce}$ is the cost of negotiations.

$\mathrm{Cc}$ is the costs to connection with the bondsman.

$\mathrm{Cd}$ is the cost of documentary.

$\mathrm{Ca}$ is the cost in the price assessment of assets.

Comparison the size of the cost of negotiations in each agreement was the size of expenditure in emergency agreement as the minimum size of expenditure is within a day while the size of expenditure in ordinary and special agreements as the increasing size of expenditure at least 2 times of the size of expenditure in emergency agreement what the size of expenditure about negotiations express the equation.

$\mathrm{CN}=\mathrm{P}+\Sigma^{40}{ }_{\mathrm{i}}{ }_{1} . \mathrm{Ce}+\left(\mathrm{Pbe}+\Sigma_{\mathrm{i}=1}^{40}\right.$ Cbee $)$

By that

$\mathrm{CN}$ is the cost in negotiations.

$\mathrm{P}$ is duration (days); a day is an emergency agreement, 7-30 days are ordinary and special agreements.

$\mathrm{Ce}$ is the size of expenditure (Baht).

Pbe is the unexpected duration.

Cbee is the size of cost in occurring expenditure from the normal duration.

When analyzing the cost in negotiations from the persons who were interviewed with 40 persons found that the expenditure costs 4,431 baht or $0.16 \%$ of total loans.

For finding the product quality of borrowers who can be split into two types as finding by network, representing $82.5 \%$ of all findings. Including, finding by a new comer or finding without a network, representing $17.5 \%$ which affect the different expenditure in the finding.

The cost of the quality finding of product brand can be written as the following equation.

$\mathrm{C}_{\mathrm{Q}}=\Sigma^{40}{ }_{\mathrm{i}}={ }_{1}(\mathrm{Cn}+\mathrm{Cw}+\mathrm{Ccp}+\mathrm{Cin})$

By that

$\mathrm{C}_{\mathrm{Q}}$ is the cost of quality finding.

$\mathrm{Cn}$ is the cost in connection to sellers.

$\mathrm{CW}$ is the cost for traveling to inspect more products.

Ccp is the cost of brand comparison.

Cin is the cost in internal connection.

Such analysis of the costs associated with the quality finding of product brand. From the persons who were interviewed revealed that the size as $1,656 \mathrm{Baht}$, calculating $0.06 \%$ of total loans. Leading to the expenditure on goods and services.

Accordingly, the regulations of cooperative will be the person paying to seller as if the cooperative acts as ownership, later, sold to the borrowers who can be considered that the transaction is completed. The cost associated with the product of individual borrowers can be obtained from the equation formula.

$\mathrm{C}_{\mathrm{Gi}}=\mathrm{Cn}+\mathrm{Cf}$. 
By that

$\mathrm{C}_{\mathrm{Gi}}$ is the size of expenditure on goods of the borrower.

$\mathrm{Cn}$ is the cost of connection to seller.

$\mathrm{Cf}$ is the cost of fuel for transportation or freight charges.

For the total size of expenditure on all products in a cycle was obtained from.

$\mathrm{CG}=\sum \mathrm{Co}+\sum \mathrm{Cs}+\sum \mathrm{Ct}+\sum \mathrm{Cop}$

By that

$\mathrm{C}_{\mathrm{G}}$ is the size of cost on the products in a cycle.

$\mathrm{Cm}$ is the size of cost by paying themselves.

Cs is the size of cost by paying in location for trading and services.

$\mathrm{Ct}$ is the size of cost to transfer.

Cop is the size of cost by the owners, such as the contractor fee.

The study found that the transaction cost related the expenditure associated with the products from the persons who were interviewed amount 40 persons with the total cost is 1,645 Baht of a cycle for loans, representing $0.06 \%$ of total loans.

From the transactions exchange agreement in accordance with a legal act that occurs as the agreement price but meaning to the guarantees of the rules that membership is faced with the complexity of benefits of the contracting parties. Since it was found that 24 persons, representing $60 \%$ of the contractors assurances to each other. This means that the pressure power shows strength in compliance with the agreement of both parties reflect the possible expectation that most of its membership will comply with the agreement of the existing rules.

When sum of the study will be seen clearly that it can be written in the form of equation in cooperative Agreements in accordance with a legal act. From a cycle of lending of the sample group is 40 samples as.

$\Sigma^{40}{ }_{\mathrm{i}=1} \mathbf{C}=\Sigma^{40}{ }_{\mathrm{i}=1} \mathrm{C}_{\mathrm{D}}+\Sigma^{40}{ }_{\mathrm{i}=1} \mathrm{C}_{\mathrm{N}}+\Sigma^{40}{ }_{\mathrm{i}=1} \mathrm{C}_{\mathrm{Q}}+\Sigma^{40}{ }_{\mathrm{i}=1} \mathrm{C}_{\mathrm{G}} \mathrm{C}$

When $\mathrm{C}$ is the transaction cost in a cycle of lending $=2166+4431+1656+1,645=9,898$ Baht or $0.35 \%$ of lending money as 2,793,000 baht. That means the end of a cycle of lending, it costs the transaction cost which membership faces the size of loan as $0.35 \%$. This equation formula can be expressed by the loan from the average loan amount of 69,825 Baht.

To study the goodwill's structure of the influence of increasing savings from the cooperative's goodwill by the study from questions that selected or not selected.

As a result, the goodwill was shown by an open question to those persons who were interviewed said that the reason for the membership to $50 \%$ from its ease of working performance. The financial system was found that persons who were interviewed selected using the principles of trading as $80 \%$, the principles of lending as $67.5 \%$, the principles of guarantee as $57.5 \%$ and the principles of partnership as $50 \%$, reflecting the principles of marketing are new knowledge to adopt the birth of a financial transaction service, in other word, performance efficiency was used to attract membership while the cooperatives in general, it is not. The cooperative has established a duty of self-organization in a position to raise money savings and trade. At the same time, which can do the specific cooperative where is approach of religious services because membership of the cooperative does not relate with money systems, but can change as the objects, therefore, the becoming of two duties at the same time, although now that act of cooperative activities performance did not write these kinds of activities in the type of any cooperative (Determine the type of registered cooperatives:2005). Although being the type of saving cooperative that does not permit trade. But compliant permit conducts commercial activities resulting in new marketing and customer base, particularly the religion, which is consistent with $65 \%$ of the conditions of practice and complete agreement. This is all consistent with the principles of religion of Muslim tradition.

$7.5 \%$ of those persons who were interviewed are brotherhood during the Muslim that reflects the organization culture of the staff to membership have been more relationships in the form of a private agreement, which makes working smoothly. Likely, $57.5 \%$ of staffs are with convenient service to create good image of the organization and the other is $7.5 \%$ that have the potential and experienced staff to working performance. $5 \%$ said that there is certainty in savings that means the reputation's quality that a sustainable and long-term acceptance. For $5 \%$ of the persons who were interviewed protect money trouble is a financial institution that has been trust in the transaction that rivals to their customers or membership and the other is $5 \%$ that this Islamic financial institutions reflect the 
lifestyle that is required in accordance with the principles of Islam in the way of life and the insurance of injustice of the parties. Leading to the other party does not violate the agreement by volunteering coercion which display the lower size of transaction cost in obtaining the agreement of partnership is like public assets as part of their assets.

$90 \%$ of the duration of membership trust the network highly as requirement is membership of the cooperative continuously and strong membership base.

Consistent with the accounting data of the growth of its membership found that the cooperative has an increasing average membership base as $18.09 \%$ since B.E. $2007-2009$ and has a margin of cooperative from 7.5 to $13.5 \%$ per year, while the cooperatives in general's profit rate are 5\% per year represents the driving force of the principles of cooperative marketing with the abundant profit from the branches of production are similar to each other. Because differences in thinking a profit in the type of the principles of trade are to increase the portion of profits from the price of products once in a while to reduce opportunistic behavior of its membership because it is agreement exchange that is not allowed touching money in trading make a profit of plenty.

Analysis the goodwill valuation from capital in the organization reflects the figure of account that compensation on revenue from marginal revenue is worth more than the change in transaction cost (the cost of litigation) what shows that goodwill is positively valued ( $\mathrm{MR}>\Delta \mathrm{TC}$; transaction cost). And net profit after the transaction cost was deducted (the cost of litigation) are likely to increase at the lower rate resulted the goodwill valuation and total assets of the cooperative has the same characteristics.

Compensation on revenue from the average coefficient of profit from distributions or services in the year of 2007-2009 was 0.07, 0.11 and 0.18, respectively. Thus, compensation on revenue from marginal revenue increased by 0.66 Baht in the year of 2008, rising to 2.37 Baht in the year 2009 increased by $259.09 \%$ (see Figure 2).

Reducing the transaction cost of cooperative or reducing cost relating to the cost of litigation due to activities performance that are associated with the transaction cost in the agreement that way to force compliance with the agreement, which is the debt tracking of debtor. There are 3 ways: 1. Payment by saving account and the existing share account are $20 \%$ of the debtor during tracking 2 . Settlement at resident is $5 \%$, lastly, 3 . Payment by credit results $5 \%$.

Calculated the total goodwill on the basis of cooperative's profitable assessment $\mathrm{Gf}=\operatorname{Pro}_{\text {net }}(\mathrm{A} * \mathrm{NRc})$. By that Pro ${ }_{n e t}$ is a net profit, $A$ is the annual value of assets and $\mathrm{NR}_{\mathrm{c}}$ is the compensation rate on assets. The average amount of assets and the sale or credit services etc. Summary all 3 years as 122,876,131.46 Baht for the goodwill valuation in the year of 2007, 2008 and 2009 are 357.45, 1894.29, 9498.22 Bath, respectively. Next, it reflects the increasing amount of goodwill from the sale of assets each year.

\subsection{Investment in the goodwill and influence the growth of goodwill.}

Investment in the goodwill influences the size of change in the goodwill valuation, which is an investment (see Figure 2). The payment or investment that the Figure 3 shows that the fist position a magnitude of change in expenditure of Zakat (like a tax after profit in accordance with the principles of Islam) and capital create educational institutions and education management, changing the size of line's slope is the same which shows that such investment has influenced the size of goodwill clearly. The second position is the size of expenditures concerning cash for welfare capital. The last position that the size of change in expenditure is similar as cash was paid for cooperative office foundation, funds for the cooperative's education and training, cash for public capital, bonus for officers and employees, investments in Hat Yai Wittayakarn School that such investment which indicates the increasing of investment in the first position that has dramatic effected on the meaning of an increase in shareholders as graph.

The increase of goodwill that will be seen the membership base to increase is influence of the increase of goodwill valuation of the cooperative will be seen that the increase in membership base of the cooperative consists of a decreasing rate due to described above to change the investment in goodwill increased at a decreasing rate affects the cooperative's goodwill valuation and, ultimately, the cooperative will contribute to the increase of shareholders in the organization increased a decreasing rate as well (see Figure 4).

Therefore, assessment to the complexity of the principles of Islam are brought a new phenomenon in the assessment of good reputation of the organization that is correlated with the size of transaction cost of the organization bring to the reputation valuation as positive. This is non-material assets that are under subconscious to the practice of working with the size of transaction cost due to the application of the principles of Islam with the perfect marketing in the form of credit cooperative and trade, which makes cooperative with a good reputation. While the investment of a figure of account for long-term investment was the goodwill valuation calculated total goodwill on the basis of valuation profit to the cooperative where influences on increasing the membership base in the organization, is a 
practice which resulted on increasing value in terms of economic movement and should be valued for its use.

\section{Conclusion}

Bringing the principles of religion to the cooperative's marketing resulted in the lower transaction cost, however, to reduce the transaction cost could apply to the operating line is a complete data distribution such as communication system management between branches, providing a guidebook for a loan to those membership that can reduce the transaction cost from information that is not clear of their working performance. That transaction cost decreases the size down as 317.40 Baht or $2.36 \%$ of the size of expenditure in a week, a change in the cost of function for activities performance in the agreement and is able to reduce the transaction cost and the size of expenditure in finding the information of borrower as 2166 Baht or decrease of total loans as $0.07 \%$ made the cooperative, which has increased significantly revenue effect the structure of the cooperative's goodwill in the market. Investment in the goodwill that reflects the long-term assets that cooperative should be to invest continuously is the size of the first position such as the size of Zakat and funds to educational institutes foundation and other positions of the investment which has no great influence to the goodwill valuation as reflected in compensation on assets, what were sold the increasing value. The increase of goodwill related to investments in non-material assets is an organization directly, so the risk depends on cooperative. However, the cooperative's goodwill makes an adding profit rather than general assets compared to the same cooperatives.

\section{References}

Aleksejev, M.M. (1997). Planirovanije deyatelnosti firmy: Uchebno-metodicheskoje posobije. Moscow: Finansy i statistika.

Alerding, R. James. (2003). Valuation of Personal Goodwill. American Academy of mantrimontial Lawyers.

Al-Quran, Surah Al - Baqarah Ayah 275

As-siddeek savings cooperative Ltd. (2007-2009). Annual report.

Belen’kaya, O. (2001). Analiz korporativnyh sliyanij i pogloschenij. Upravlenije kompaniyej. № 2, (pp. 49-54). [Online] Available: http://old.e-xecutive.ru/publications/aspects/article_927 (February 16, 2011)

Bolshoj juridicheskij slovar. Pod red. Suhareva, A.Y., Krutskih, V.E. - Moscow: 2002. [Online] Available: http://www.jur-words.info/cat-0000001454-4-4.html (February 18, 2011)

Chueng, S.N.S. (1978). The myth of social costs.L.

Coase, R.H. (1992). The Comment-Contract economics: Blackwell Publishers.

Determine the type of registered cooperatives. (2005) [Online]

Available: http://webhost.cpd.go.th/rlo/download/ministerial/type_coop.pdf (January 12, 2011)

Jones, G.R., Hill, C.W.L. (1982).Transaction costs analysis of strategy structure choice. - Strategic manangement journal, vol.9, (pp.159-172)

Menar, K.(1996). Economika organizaci: Per s fr; Pod red. Hudokormova, A.G.-Moscow: INFRA-M.

Ocenka biznesa: Uchebnuk dlya vuzov (1999).Pod red.Gryaznova, A.G., Fedotova, M.A. - Moscow: Financy i statistika.

Scherbakova, O. (2008) Goodwill: vazhnejshaya sostavlyajuschaya nematerial'nyh aktivov v uchete kommercheskih predpriyatij. Audit $i$ finansovyj analiz. №5 (pp.1-6). [Online] Available: http://www.auditfin.com/fin/2008/5/Sherbakova/Sherbakova\%20.pdf (February 18, 2011) 
Table 1. The sum of the activities performance of the organization's transaction costs in a week

\begin{tabular}{|c|c|c|}
\hline The transaction cost & The indicator of transaction cost & $\begin{array}{l}\text { Size } \\
\text { (Baht) }\end{array}$ \\
\hline $\begin{array}{l}\text { The perceptible information is } \\
\text { not clear. }\end{array}$ & $\begin{array}{l}\mathrm{Ca}=\Sigma\left(\mathrm{L}^{*} \mathrm{~T}\right) \\
\mathrm{Ca}=\text { the cost of counseling, } \mathrm{L}=\text { wage }(\text { Bath), } \mathrm{T}=\text { time (minutes). }\end{array}$ & 123.90 \\
\hline Consideration & $\begin{array}{l}\mathrm{Cn}=\Sigma(\mathrm{L} * \mathrm{Tp}) \\
\mathrm{Cn}=\text { the cost of negotiations, } \mathrm{Tp}=\text { the time is an obstacle to working (minutes). }\end{array}$ & 31.50 \\
\hline Agreement & $\begin{array}{l}\mathrm{Cn}=\Sigma\left(\mathrm{L}^{*} \mathrm{Tpn}\right) \\
\mathrm{Tpn}=\text { the time is an obstacle to negotiations. }\end{array}$ & 21.00 \\
\hline Trades and services. & $\begin{array}{l}\mathrm{Cc}=(\mathrm{Lb} * \mathrm{~T})+\mathrm{Cn} \\
\mathrm{Cc}=\text { the cost of contact. } \\
\mathrm{Lb}=\text { the wage of non-related persons, } \mathrm{Cn}=\text { the cost of contact. }\end{array}$ & 141.00 \\
\hline Precipitation & $\begin{array}{l}\mathrm{Cca}=\mathrm{n} * \mathrm{~L}^{*} \mathrm{Cn} \\
\mathrm{Cca}=\text { the cost of agreement, } \mathrm{n}=\text { number of employees with feedback. }\end{array}$ & 31.50 \\
\hline Debt tracking. & $\begin{array}{l}C_{D}=T d * n * L * d, C n=T c * n * L * d \\
C d=\text { the cost of finding, } T d=\text { time to finding, Tc = time of negotiations, } n=\text { number of } \\
\text { membership, } d=\text { number of day per fieldtrip in a week. }\end{array}$ & 882.00 \\
\hline Investment activities. & $\begin{array}{l}\mathrm{Cc}=\mathrm{L} * \mathrm{n} * \mathrm{Ct} . \\
\mathrm{Cc}=\text { the cost of coordination to bring to an agreement. } \\
\mathrm{n}=\text { number of people who attend the meeting. } \\
\mathrm{Ct}=\text { the cost per a call in the negotiations. }\end{array}$ & 74.25 \\
\hline $\begin{array}{l}\text { The invention of standard } \\
\text { brand. }\end{array}$ & $\begin{array}{l}\mathrm{Ccb}=(\mathrm{Cin}+\mathrm{Co})^{1 / 4} \\
\mathrm{Ccb}=\text { the cost of qualitative innovation. } \\
\mathrm{Cin}=\text { the cost of internal contacts. } \\
\mathrm{Co}=\text { the cost of external contacts. } \\
1 / 4=\text { the occurring cost during in a cycle of month. }\end{array}$ & 340.84 \\
\hline The principles of marketing. & $\begin{array}{l}\mathrm{Cc}=\mathrm{n} * \mathrm{~L} * \mathrm{~T} \\
\mathrm{Cc}=\text { the cost of negotiations } \\
\mathrm{n}=\text { number of employees. } \\
\mathrm{T}=\text { time of negotiations. }\end{array}$ & 45.00 \\
\hline Total & $\mathrm{Ca}+\mathrm{Cn}+\mathrm{Cn}+\mathrm{Cc}+\mathrm{Cca}+\mathrm{C}_{\mathrm{D}}+\mathrm{Cc}+\mathrm{Ccb}+\mathrm{Cc}$ & $1,690.99$ \\
\hline
\end{tabular}

Source: Field Work 2010

Table 2.The new information (Perceptible information is not clear) of the members after trainin

\begin{tabular}{|l|c|c|c|c|c|c|c|c|}
\hline Frequently Questions & \multicolumn{2}{l|}{$\begin{array}{l}\text { Total } \\
\text { (Person) }\end{array}$} & \multicolumn{4}{|l|}{ The size of transaction cost (Baht) } \\
\cline { 4 - 8 } & 5.25 & 6.30 & 8.40 & 9.45 & 10.50 & 21.00. & 31.51 \\
\hline How do I have? (What is my right?) & 8 & 4 & & & 1 & 1 & 1 & 1 \\
\hline $\begin{array}{l}\text { Investigation by itself. (How do the membership accords with these } \\
\text { rules and regulations?) }\end{array}$ & 3 & 1 & 1 & & & 1 & & \\
\hline Is there another way? (Credit access) & 1 & & & 1 & & & & \\
\hline
\end{tabular}

Source: Field Work 2010

Table 3. The credit access to agreement of its membership

\begin{tabular}{|l|c|c|c|c|c|c|c|}
\hline Type of agreement in accordance with objectives and the credit access \\
\hline Objective & Total (Person) & \multicolumn{2}{|c|}{ Emergency } & \multicolumn{2}{|c|}{ Ordinary } & \multicolumn{2}{|c|}{ Special } \\
\cline { 3 - 9 } & & Known & Unknown & Known & Unknown & Known & Unknown \\
\hline The product or the contractor fee. & 36 & 1 & & 9 & 22 & 3 & 1 \\
\hline The debt payment + the educational register fee. & 4 & 2 & 2 & & & & \\
\hline
\end{tabular}

Source: Field Work 2010 
Table 4. The cost of information finding the credit access

\begin{tabular}{|c|c|c|c|c|c|c|c|c|c|c|}
\hline \multirow[t]{3}{*}{ The information finding } & \multirow{3}{*}{$\begin{array}{c}\text { Total } \\
\text { (Person) }\end{array}$} & \multicolumn{9}{|c|}{ The size of transaction cost (Baht) } \\
\hline & & \multicolumn{3}{|c|}{ Connection } & \multicolumn{3}{|c|}{ The cost of fuel } & \multicolumn{3}{|c|}{ The opportunity cost } \\
\hline & & 0 & $5-10$ & $>10$ & 0 & $10-20$ & $>20$ & 0 & $30-120$ & $>120$ \\
\hline 1. Network: relatives, friends. & 6 & 3 & 2 & 1 & 4 & 2 & 0 & 5 & 1 & 0 \\
\hline 2. Network: Colleagues. & 5 & 2 & 1 & 2 & 4 & 1 & 0 & 5 & 0 & 0 \\
\hline 3. Cooperative & 19 & 16 & 3 & 0 & 0 & 13 & 6 & 9 & 7 & 3 \\
\hline 4. Both the network and the cooperative. & 3 & 1 & 1 & 0 & 0 & 2 & 1 & 1 & 0 & 2 \\
\hline 5. The complete understanding of the data. & 7 & 7 & 0 & 0 & 7 & 0 & 0 & 7 & 0 & 0 \\
\hline
\end{tabular}

Source: Field Work 2010

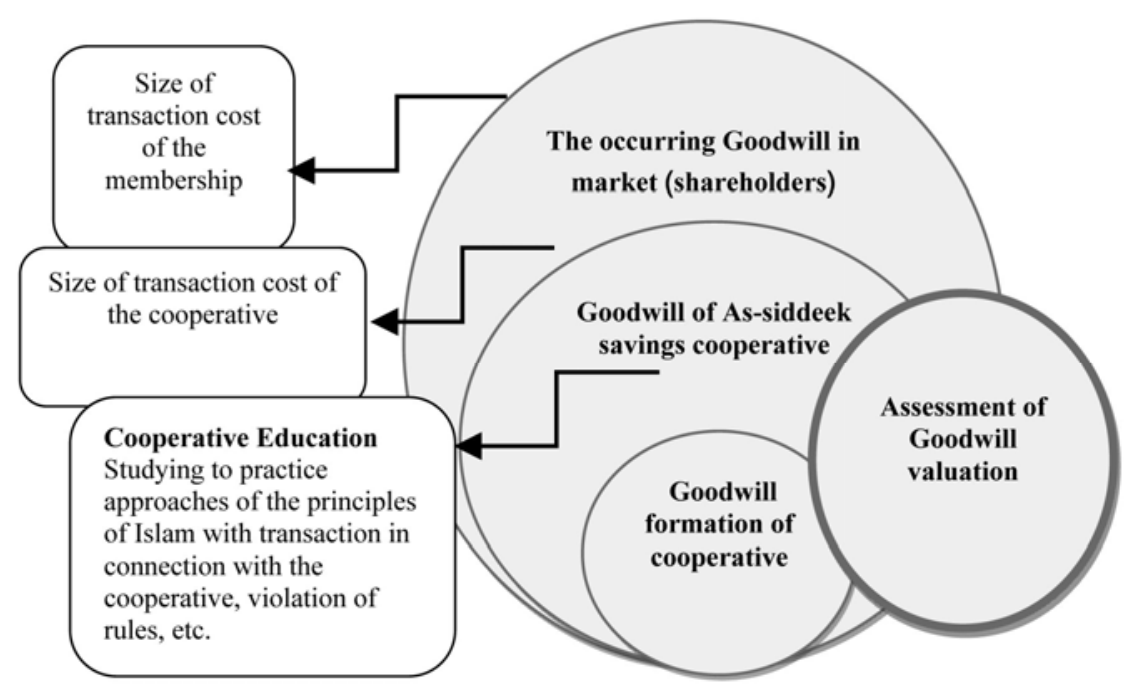

Figure 1. Framework for research.

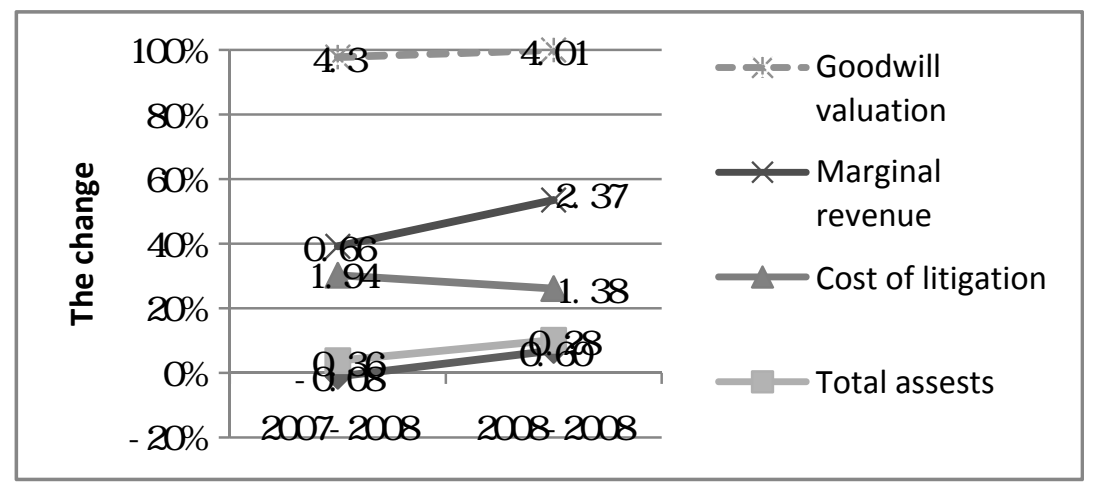

Figure 2. Compensation on revenue and the goodwill valuation in the cooperative. 


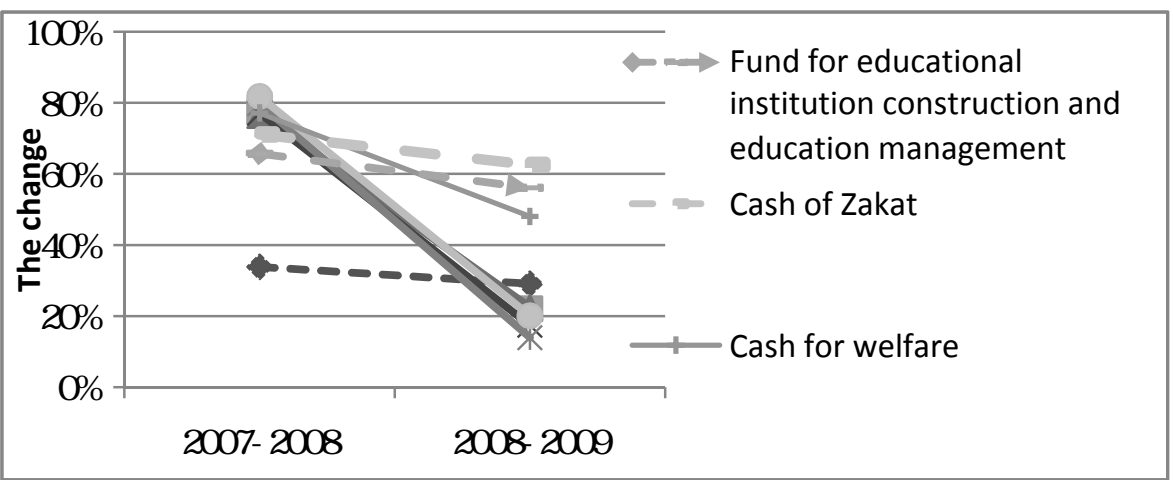

Figure 3. Investment in goodwill and influence the growth of goodwill.

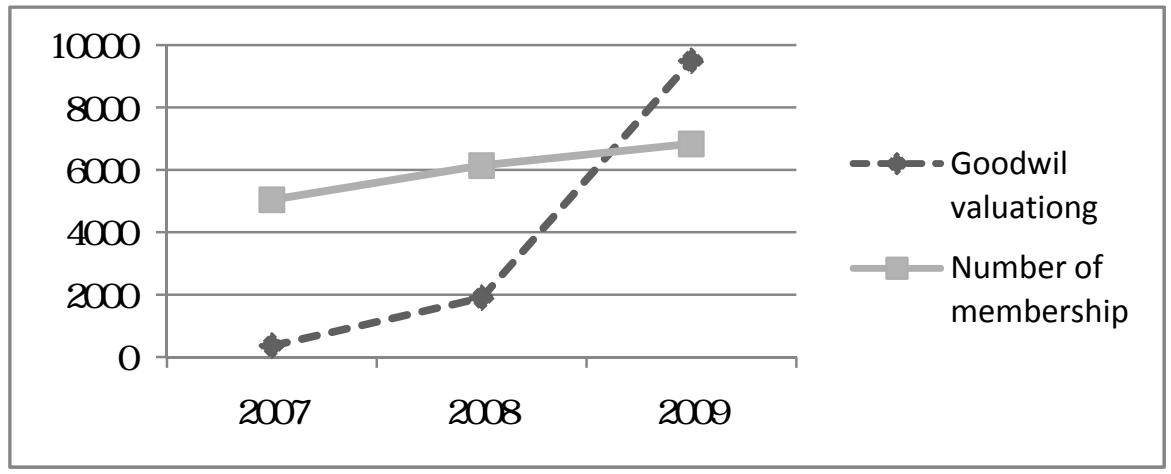

Figure 4. The number of membership increased by the increasing goodwill valuation in each year. 